\title{
An Introduction to Architecture of Nasir Al-Mulk Mosque
}

\author{
Azin Ehteshami, Mehdi Soltaninejad \\ Architecture and Planning Department of Art University of Isfahan, Isfahan, Iran \\ Email: azin.ehteshami68@gmail.com, medi.solt84@gmail.com
}

How to cite this paper: Ehteshami, A. and Soltaninejad, M. (2019) An Introduction to Architecture of Nasir Al-Mulk Mosque. World Journal of Engineering and Technology, 7, 652-675.

https://doi.org/10.4236/wjet.2019.74048

Received: October 14, 2019

Accepted: November 26, 2019

Published: November 29, 2019

Copyright $\odot 2019$ by author(s) and Scientific Research Publishing Inc. This work is licensed under the Creative Commons Attribution International License (CC BY 4.0).

http://creativecommons.org/licenses/by/4.0/

\begin{abstract}
In analazying the form in architectural monuments or in a more comprehensive way, study of the monuments itself is one of the most fundamental and most important aspects of architecture that has several benefits and effects. One of the benefits of recognizing the shape of different building architecture is the categorization of architecture into different historical periods that can help us better understand the process of historical architectural developments in the past. Among the architectural monuments of Iran, Nasir al-Mulk Mosque in Shiraz which is a Qajar Mosque is one of the most important Mosques in Shiraz which is less focused in the previous studies. This article, which is mainly based on empirical research and field studies, was conducted for studying the architecture of the mosque and analyzing and explaining the most important architectural features of this monument. The main questions of this article are the following: 1) What are the most basic architectural features of Nasir al-Mulk Mosque and how different parts are organized and built next to each other? 2) What choices and opting out of the architectural design of the building have been carried out? To find the best answers to these questions, first we analyzed the structure and overall fitness of the Mosque and its characteristics had been enumerated. Then, we introduced and analyze the main sectors that make up the corpus such as the mosque entrance, courtyard, naves and porches, in which the form and structure of each of these sectors as well as their consort with each other in shaping the overall architecture of the mosque, are analyzed and discussed. The summary of the findings in the form of empirical statements is presented at the end of the article.
\end{abstract}

\section{Keywords}

Iranian Architecture, Qajar Mosque, Shiraz Mosque, Nasir Al-Mulk Mosque

\section{Introduction}

In analazying the form in architectural monuments or in a more comprehensive 
way, study of the monuments itself, is one of the most fundamental and most beneficial aspects of studying the monuments. Fundamental in this respect that the architectural researcher or other addresses before choosing to speak of other aspects relating to development of architectural monuments has to closely face the monument itself and identify its benefit in this aspect that identifying the monument itself produces many other questions which may be asked of other existential aspects of the monument.

Here and in Iran past architecture, Iranian mosques are among the most important historical buildings that may be studied in various aspects. In this study, our intent is to study Shiraz Nasir al-Mulk Mosque, Qajar Mosque whose architectural features have been rarely addressed. Here, our main questions include:

- What are the main features of architectural design of this mosque?

- What parts of the mosque building have been constituted and what features each of these parts have?

- How various parts of the building are placed beside each other and are organized?

- What selections and dissuasions have been made in this architectural design?

In answering these questions, one of main hypotheses is that the architectural monument itself (regardless of the way they are created) has many big and small points for study and presentation. Also, the comprehensive study of the architectural monument is the study which exceeds the domain of the monument itself and considers its various creating factors, but hypothesis is that studying the monument itself is preferential to other aspects of studying it and is the main predisposing factor of other studies. In fact, other questions such as questioning the monument style (that is various contexts where the monument is created) also originate from the monument itself. The aim of studies like the present research is that besides helping in deeper perception of the architectural monument, it provides a field for opening other layers of perception and its study and this by itself, which indicates significance and necessity of such studies. In writing this article, it has been tried that by avoiding terms and plausive tone common in many articles of this area, addressing the tangible and sensible aspects of monument study and analyzing the building architecture as it presents itself and in this way, opens the door for identifying some hidden principles and rules in the monument face.

\section{Research Methodology}

This research specifically is mainly an experimental research and the answer to its questions is experimental predicates which have been obtained based on an exploratory basis. The most important instrument of this study has been a close encounter to the monument itself (field study) in several steps which have been preceded with description and analysis of the architecture and design of the mosque utilizing prepared maps and pictures. So, the present study more than relying on other written sources and such document, is based on reading the monument itself. 


\section{A Short Summary of the Mosque History}

Referring to the historical inscriptions of the building, the construction of mosque had begun in 1876 and continues 12 years till 1888. So, the mosque belongs to Qajar era (the time of reign of Naseraddin Shah). This mosque has been registered on 1 February 1956 under number 396 in the list if Iran historical monuments.

The sponsor of the mosque has been Mirza Hassan Alikhan Nasirolmolk son of Mirza Aliakbar Ghavamolmolk one of Shiraz grandees [1]. Its architect name was Mohammad Hassan and the designer of its tiles was Mohammadhossein Naghash Shirazi and Mohammadreza Kashipaz Shirazi. This mosque is located in the Shiraz Gud Araban quarter in south of current Lotfalikhan Zand Street. Gud Araban and Darb Sheikh are among old quarters in the main contexture of Shiraz that in the map relating to Qajar era has been subset of a bigger quarter called Eshagh Beig.

\section{Building in the Contexture}

The mosque has so matched in the contexture that in an aerial view its only distinction with the surrounding buildings is its special orientation towards the Keblah and also its big size. In two southern and western directions, the mosque is adjacent to surrounding buildings, while there are two passages in its two eastern and northern sides (Figure 1). This adjacency has generally influenced the shape of mosque land and it seems that during the construction of mosque, they didn't have so much difference with their present status. Apparently, the architect has used all land area for construction of the mosque and he hasn't scarified any of its angles and breakages for creating regular geometrical shape. What separates the mosque from its surrounding contexture are two narrow alleys in its north and east and this has caused the building to become very close to its surrounding houses (Figure 1).

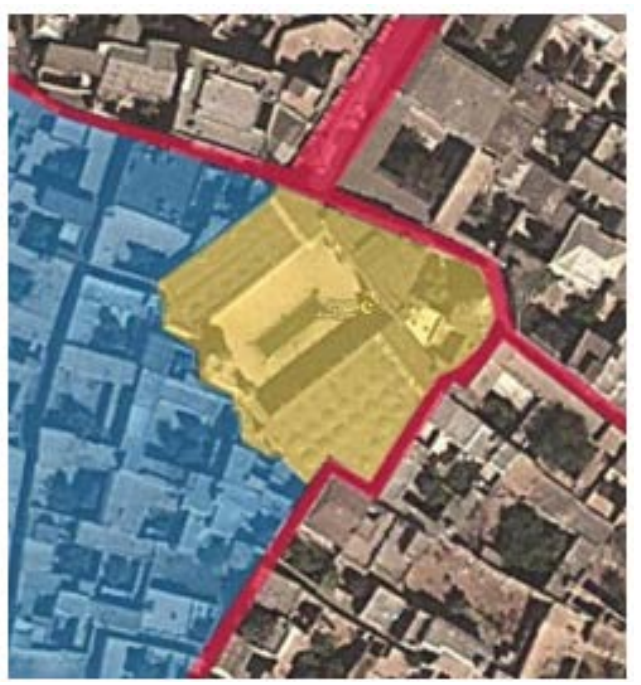

Figure 1. The building in the contexture (Source: author). 
In fact, the only angle where the mosque may be observed of relatively long distance is the alley in front of its entrance and the entrance is the only external presentation of the building (Figure 2). These features, in one hand, and lack of minaret in the mosque, on the other hand, cause creation of a tangible introspection of its building. Until we haven't entered the building, we know nothing of it. Nor we can turn around it, neither any high sign of it can be observed, and not even it may be looked from the top of higher buildings around it. Everything happens inside and this doubles the curiosity of the viewer when for the first time faces the mosque interior.

\section{Totality of the Body and Manner of Establishment of the Building}

The mosque has been made in a land plot with area of $2980 \mathrm{~m}^{2}$ and with infrastructure of $2414 \mathrm{~m}^{2}$ and the mosque building has been made so that its south side is upright to the Kiblah axes. By looking at the building aerial figure, the first thing which attracts attention is the land irregular shape which is due to adjacent buildings shape and the passages around the mosque (Figure 3 \& Figure 4).

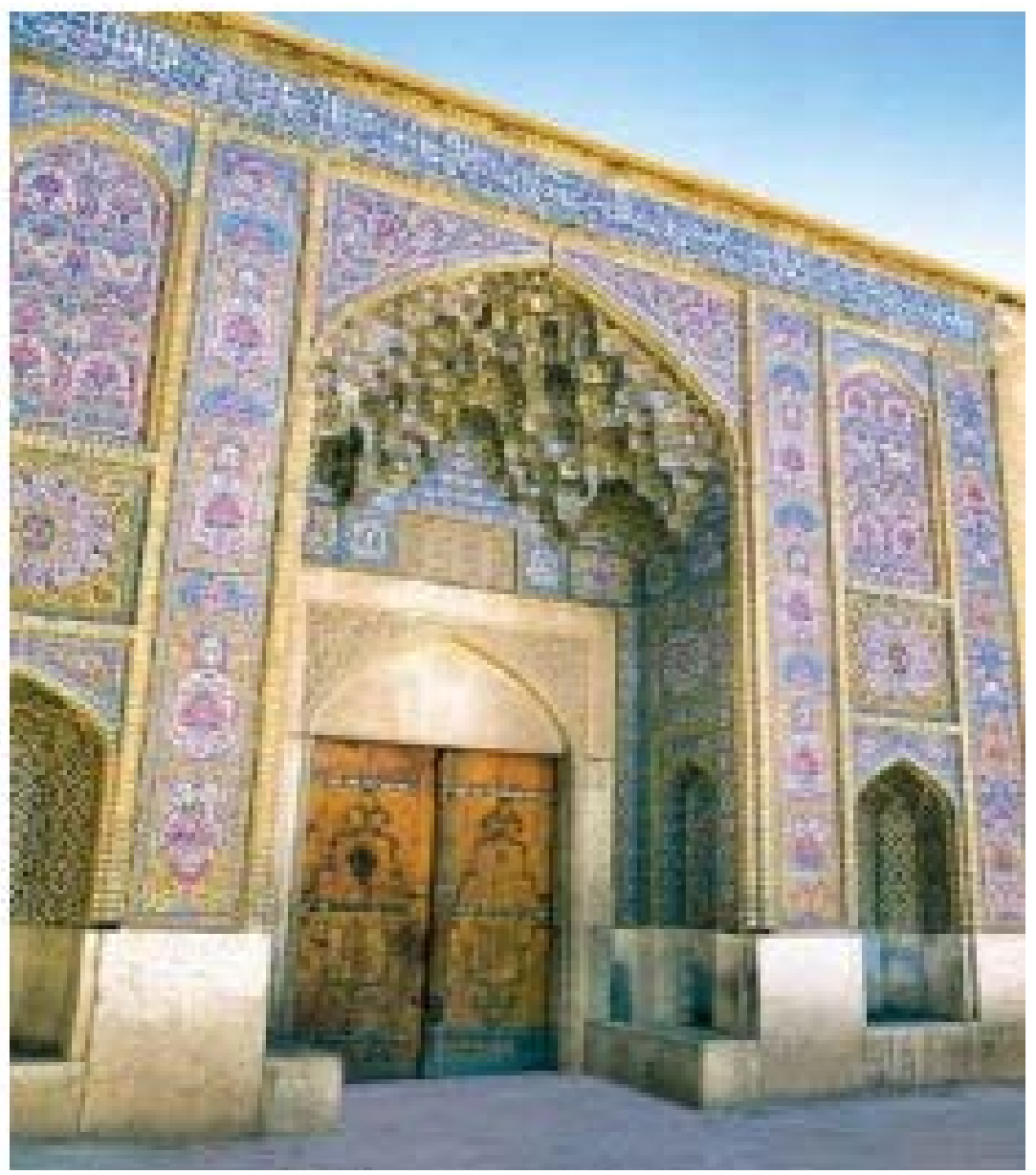

Figure 2. The entrance portal (Source: author). 


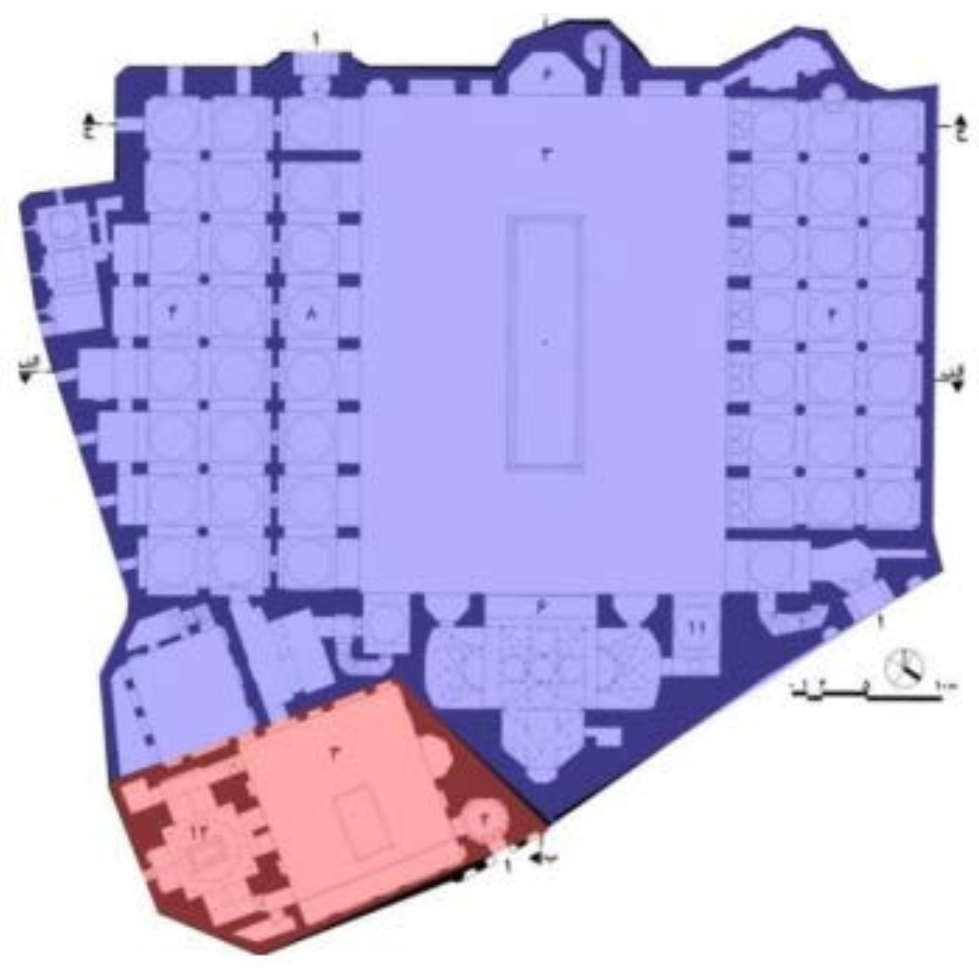

Figure 3. Plan of the ground floor (Source: Hajighasemi, 2003 [2]).

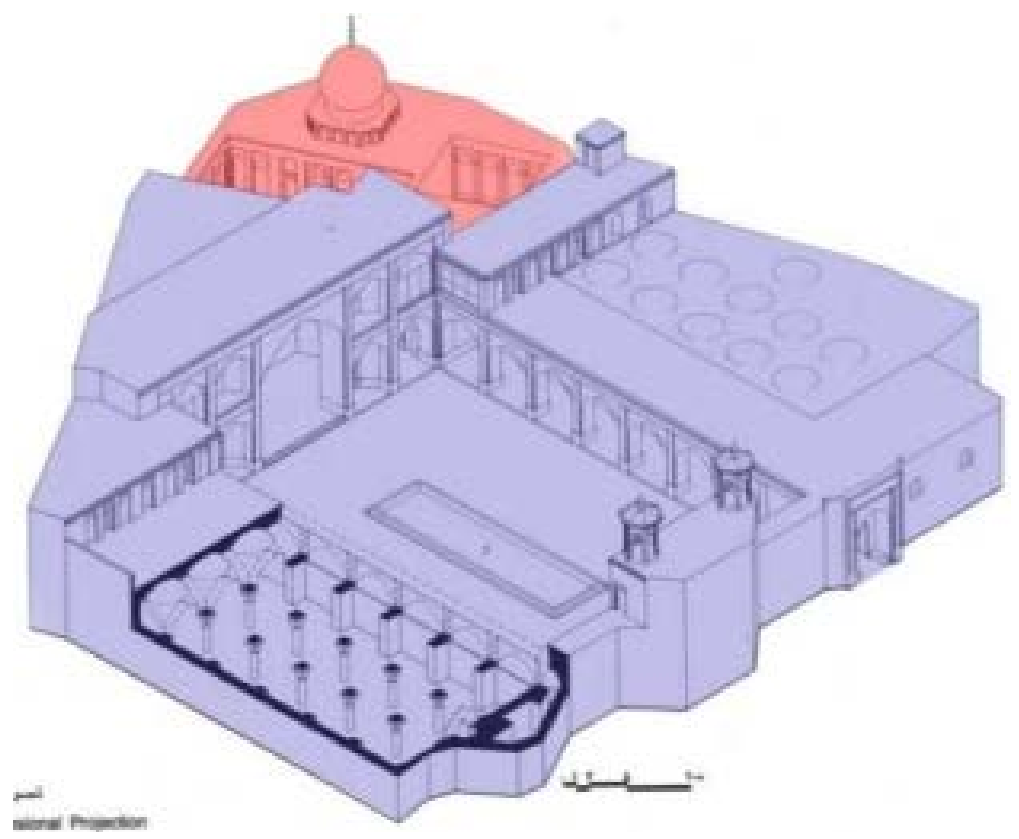

Figure 4. Isometric perspective (source: Hajighasemi, 2003 [2]).

In fact, the building has two main parts: 1 ) the mosque (blue color in the figures), 2) the building of Imamzadeh Seyed jalalding (red color). The mosque building along with the Imamzadeh building has been constructed so that the structure and general volume of both buildings have been completely knitted and attached. Emamzadeh historical inscription shows that this building is older 
than the mosque building and in fact the mosque building has been constructed besides it or better to say has been attached to it. The manner of attaching the mosque building to the Imamzadeh building is considerable. This attachment is so that two buildings despite their indirect relation are completely interwoven. From the structure of two buildings (especially in the plan) is completely clear that this close relation has been considered since the beginning of the mosque plan. The relation which of course has made the design and construction more complex (Figure 3 \& Figure 4).

Attention to the plan of Imamzadeh building clears the mistake which has occurred in the recognition of the Kiblah direction. If we consider the Kiblah direction considering the present direction of the tombstone, we will find out this problem. It is clear from the direction of standing the harems and the mosque altar that this mistake has been modified in the mosque construction (Figure 3).

Regardless of detachment of these two buildings and in a general view, the complex plan can be divided into two main parts in respect of shape: the southern part (green color) and the northern part (blue color) (Figure 5). The northern part is bigger and has a relatively regular and rectangular shaped geometry and the southern part is smaller and irregular. Possibly, this division has been considered by its architect during the building design and we can find various solutions for the designing problems provided based on it. We look at the plan once again, if we omit the Emamzadeh building from the collection that we said has previously existed, we will see the land that possibly the architect has faced it as Figure 6. It is logical that the main elements of the mosque, that is the courtyard and the harem should be placed in the rectangular regular arena (southern arena), this arena has an upper level in some of its parts, chambers in the north and minarets and their connection path in the south (Figure 7).

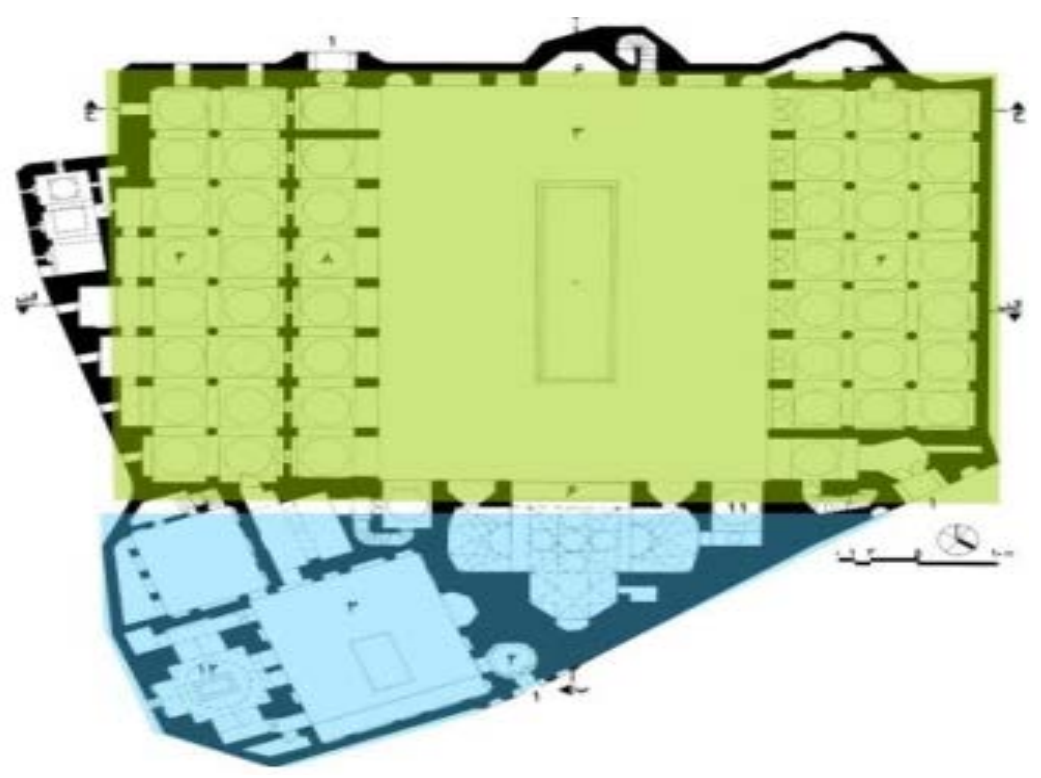

Figure 5. Source: Hajighasemi, 2003 [2]. 


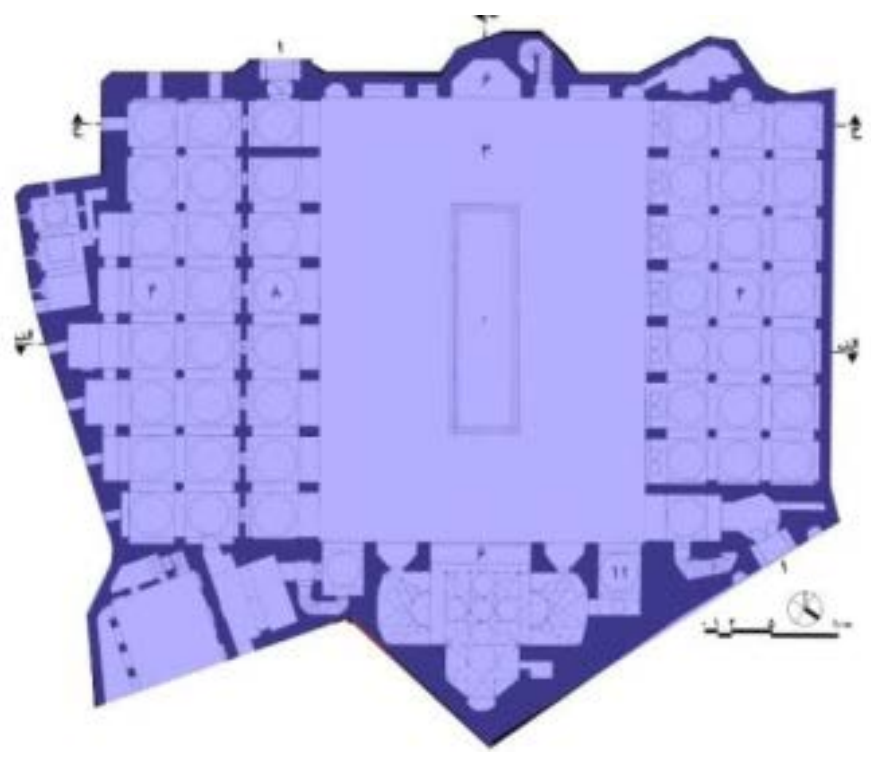

Figure 6. Source: Hajighasemi, 2003 [2].

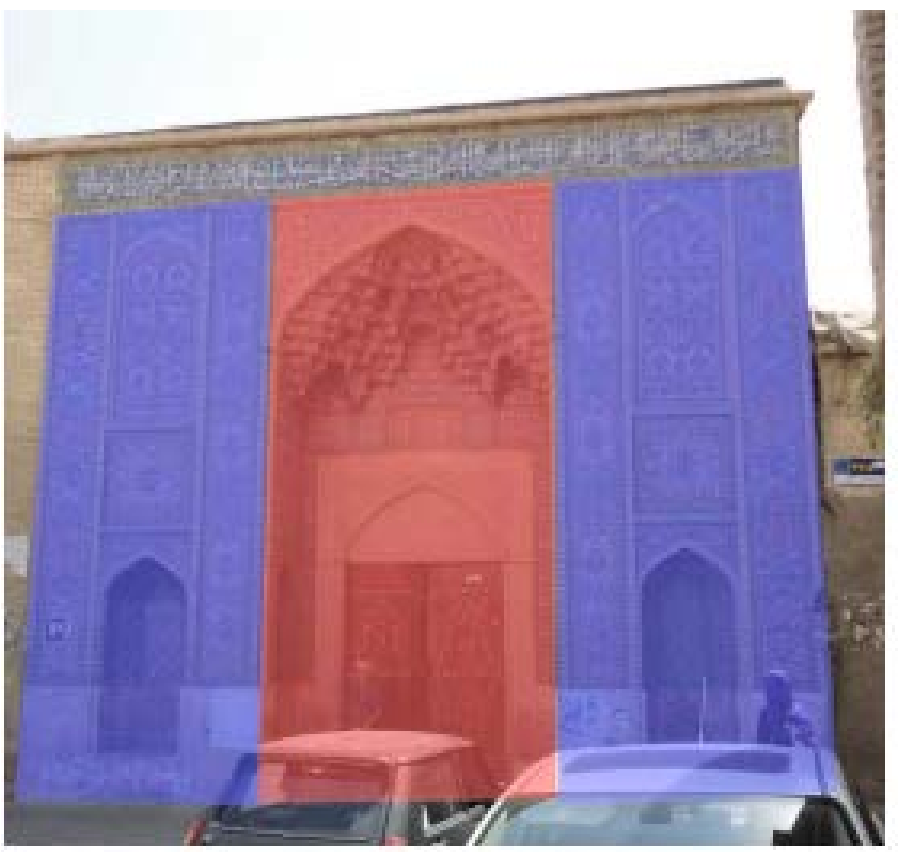

Figure 7. Entrance portal (Source: author).

But the arrangements which have been considered for the northern part are placement of the northern deep and long porch and its attachments and devising a path for the entrance of Emamzadeh building which is located in the east of northern porch. As it is obvious from the plan, the greatest diameter of the walls is related to the building northern part, where there is no trace of the rectangular geometry of the southern part and many land abnormalities have been solved inside these tick walls. The mosque main entrance is also located in a place between two north and south sections and automatically separated them from each other. So there is no doubt that the building is completely dependent to the 
shape of the land where it is located but here this dependence in the plan has been observed in the respect of occupation and adjustment not from this view that there is an obstacle in front of the designer.

What we have said till now are the subjects perceived by looking at the aerial images and the mosque plan, but in reality and from view of a viewer almost any of these points are not perceivable. By passing the mosque entrance and entering the courtyard, the main arenas of the building are completely recognizable and no trace of asymmetry is seen in the building internal sections, everything is regular and symmetrical. Sum of the mentioned specifications creates a simple but difficult status for the mosque building totality and its establishment system. That is, on one hand, the mosque general body and its establishment system is completely simple, and on the other hand, the companionship of the mosque elements and also the combination of its building with Emamzadeh building has many small and big complexities. In the following by more investigation of the building components, this subject gets clearer.

\subsection{Entrance}

The entrance portal is the only external ornamented face of the building, with a combination of tiling, Muqarnas and stone cutting which is located in the western end of the mosque northern side (Figure 2). The compressed texture surrounding the mosque, gives the least possibility of our perception of the building external totality. Lack of vault and minaret or any other distinctive element seen from outside has intensified this matter. Here the entrance portal as the representative of the building various elements stands in front of the viewer and offers a though glancing image of the whole building. Its sunken middle arch represents the mosque porch and its lateral smaller troughs indicate the altar shape. Its body detailed tiling is similar to the tiling of other parts of the mosque, as if the portal somehow recreates the building limbs in a small area and so it is very familiar. It is a window through which the whole building may be viewed though shortly. Looking at the mosques entrance (entrance porch) in this respect demands an independent opportunity and doesn't fit into this discussion. All these schemes provide an opportunity so that the building since the very beginning invites the viewer to enter a space different from outside.

The entrance portal can be divided into three main parts: the middle part which is the main part of this division and two symmetrical parts in two sides of the middle part (Figure 7). In these three sections, the dominant part is the upright and upward direction. Existence of twig arcs more emphasizes this direction. The main part (middle) includes twig arc that has about 2 meters through and incudes the building entrance portal. Under this arch is covered with detailed Mugarnas and its body (except the door frame which is of stone) is completely covered by tile. What is observed from the portal ornaments distantly, is the big and small swells and various darkness and lights which has been created with the aid of this same Mugharnas and playing with the volume. The more we get closer to the building entrance, finer layers is obvious from these 
ornaments against our eyes (Figure 8). In fact, the entrance portal decorations (and generally the mosque ornaments) have some positions in sizes and in any distance a curtain of them appears (Figure 26). From the far distance, just the general volume of the portal and its branch through is seen in a curtain nearer to various frames of tiling and smaller divisions and is obvious in a very closer to details of tiling.

All these details are located around the wooden French door with approximate width of 2 meters which are placed in the middle of stone-cutting rectangular-shaped frame. The wood warm color with the neutral color (white) has been framed with its stone margin, the frame which is a border for separating the wooden door of the ornamented tilling body around it. The interesting point in this frame is that above the main door (middle part of the stone twig arc) has been released without ornament (stone-cutting) (Figure 2). Except these stone parts where two stone platforms have been devised in both sides of the entrance bodies. The wall where these platforms relay on it has been covered with stone I almost its height. In fact, the whole body of the building entrance from the floor to approximate height of $120 \mathrm{~cm}$ is covered with stone and so the erosion in this part has been minimized.

Pink color is a notable color in the tilling of entrance and the whole mosque, to the extent that this mosque is known as pink mosque in the conversations of the local people. Patterns of flower and bird and vase are seen much among these patterns. Companionship system of these patterns is so that they can be divided into smaller frames that each has an independent roles. These roles though are independent but by locating along with each other, have made a coherent and integrated totality. The role in both sides of the entrance has a symmetrical design.

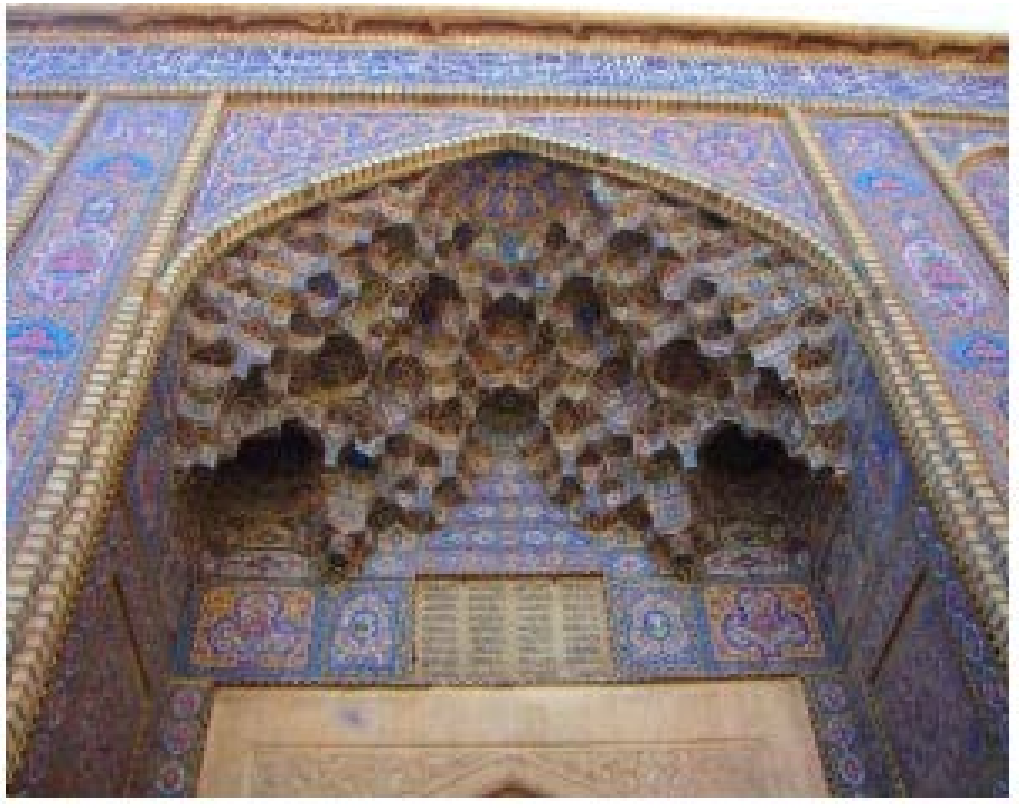

Figure 8. Entrance portal (Source: author). 
After passing the entrance portal of the mosque, we enter a space which has an almost hexagon geometry (look at the porch entrance in Figure 3) and it seems that they are purposely rotated a little so that the wall where the mosque historical inscription is located on it to be exactly placed in front of the newcomer viewer (Figure 9). Bodies of this hexagonal space have been covered by simple brickwork and only the tiled parts of the same rectangular frame are the mosque inscription and the ceiling of this space. The ceiling of this part of the porch doesn't have a specific geometry and have been covered with a combination of brickwork and tile. The entrance porch has two parts. One, the former part which was described and another, rectangular section (Figure 26). These two parts are separated with brick cradle arch. This detachment provides the preliminaries of entering the outside space of the mosque to the courtyard space with 120 degrees turn (look at the building plan in Figure 3).

As it was said, the first part of this porch has an almost hexagonal but irregular geometry but its second part is completely rectangular shaped and is considered as the regular and defined entrance for the mosque courtyard which is the rectangular geometry. The bodies of this part of the entrance are covered by brick but its cupulate shape has a detained tiling which is ornamented with decorated angles to the half of the wall (Figure 10). Totally, the entrance portal has fewer ornaments comparing the mosque internal sections and in this respect, it seems intermediate and second-degree space, a space which is located among two main elements, i.e. the entrance portal and porch. The mosque entrance regarding its location (western end of the mosque northern side) and the rotational angle which is created in the space, has solved a great part of problems and complications of the irregular geometry of this part of the mosque land and has

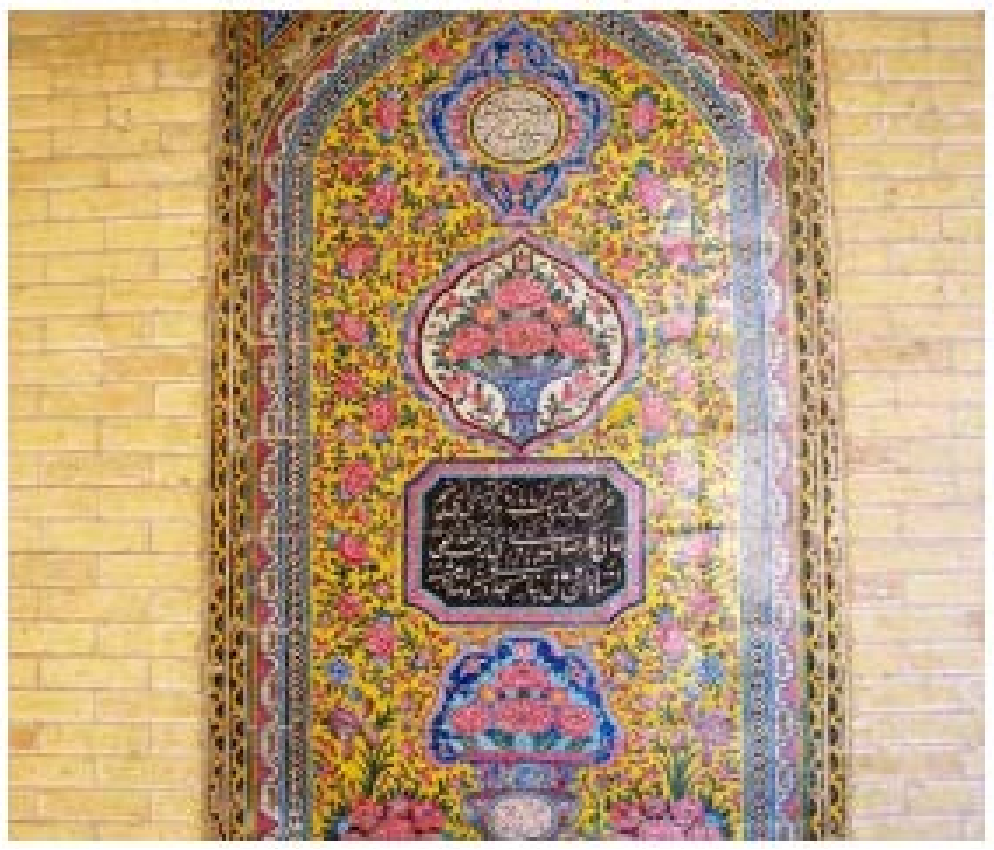

Figure 9. The mosque historical inscription in the entrance portal (Source: author). 
provided the preliminaries of providing a regular space with a clear geometry for the mosque porch and harem. One of other reasons which should be mentioned for placement of the entrance portal in this place is that now the entrance is located in the end of the passage which ends in the mosque and from the beginning of this passage, it may be completely seen. While if the entrance was for example in the middle of northern side (where is now located in the northern porch), it was not seen from the main passage and would located in the wrap. Besides the main entrance, there is a lateral entrance in the mosque southern side (overlooking to the eastern harem). This entrance is opened to the rectangular space (which can't be called porch) which leads to the courtyard (Figure 11 \& Figure 12).

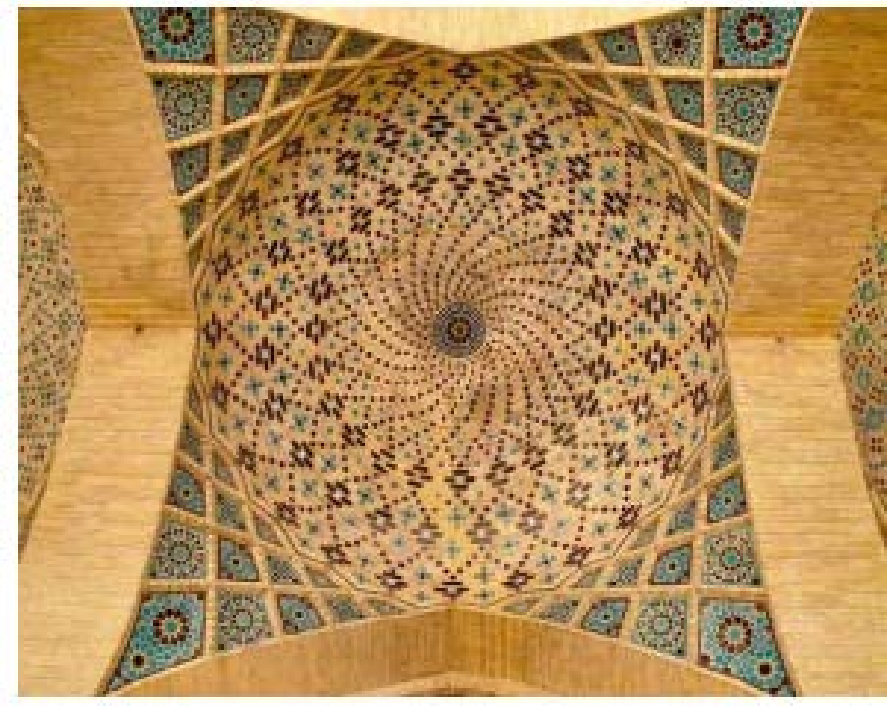

Figure 10. The ceiling of the second part of entrance porch (Source: author).

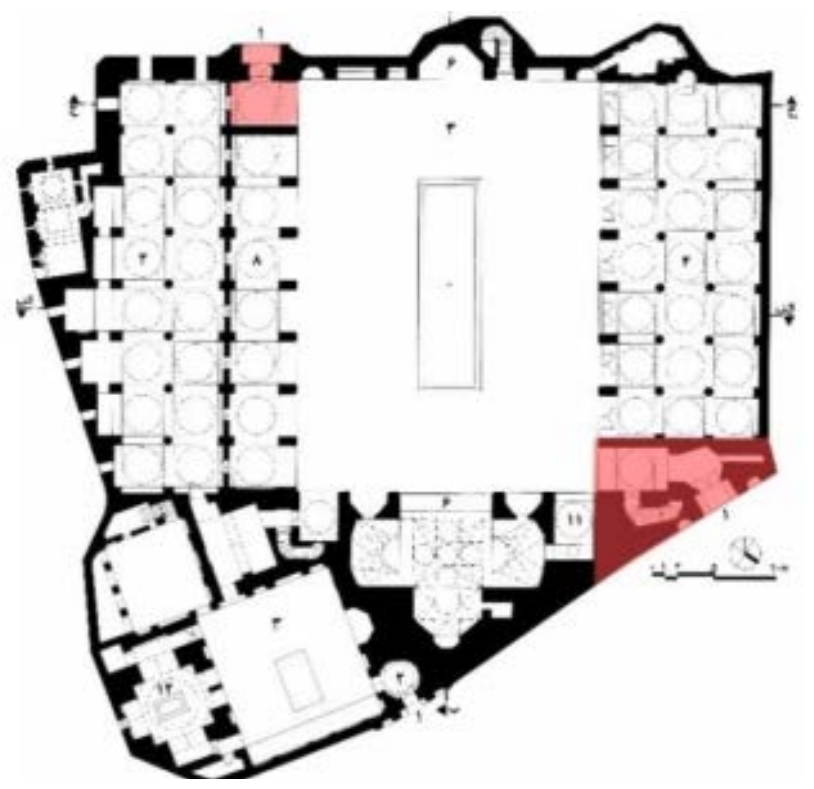

Figure 11. Main and lateral entrances of the mosque (Source: Hajighasemi, 2003). 


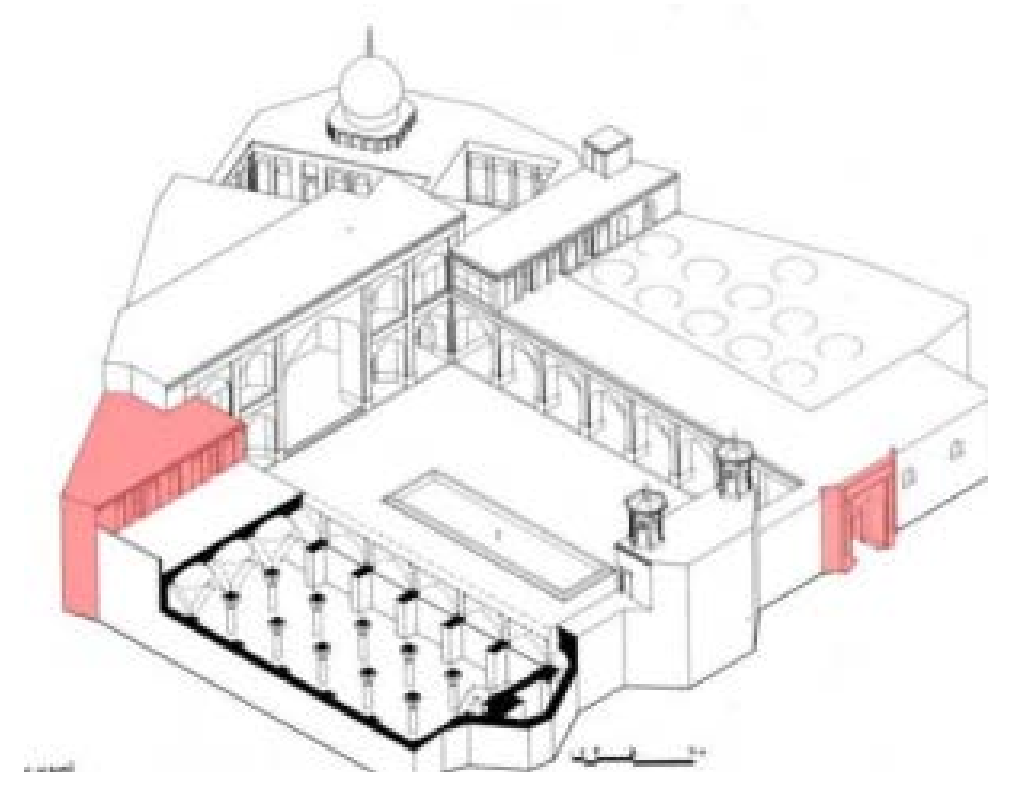

Figure 12. Main and lateral entrances of the mosque (source of perspective figure: Hajighasemi, 2003).

\subsection{Courtyard}

What we remind as the mosque courtyard is an open (but not empty) space which is the central core and heart of the building framework. We don't consider it empty since it is a place for interaction of visual forces which rise from its surrounding spaces and reach each other. In fact, the whole mosque building is like what is in the courtyard space which finds the opportunity of accession and is perceived. It is in the courtyard that we for the first time find ourselves in the building and look at the sights, recognize the arenas and determine its path and since the mosque is completely introspective and doesn't have external presentation. The courtyard significance is doubled. In the mosque courtyard, our perception of the surrounding bodies has always a perception strongly related with the whole bodies. Its square shape that its sides are in front of each other two by two, the viewer (even unconsciously) has to compare the sides. It is here that the symmetry between these elements (sides or bodies of the courtyard) finds an extra significance. The bodies around the courtyard are in fact facades of the surrounding spaces which face the courtyard. These facades though have a close relation with each other, but each has features which independently influence the courtyard space.

\subsubsection{The Courtyard Western Façade (Western Harem Façade)}

What at first attracts attention is its lateral dominant direction which is in the direction of the Kiblah axis. The proportion of height of this façade is about 1 to 6 (height of $6.20 \mathrm{~m}$ and length of about $33 \mathrm{~m}$ ). The façade has an integrated totality which is divided into 8 equal openings (Figure 13). The façade ceiling is higher due to being located on the chambers on the entrance section but since at the end the ceiling façade is flat and without fracture (Figure 14). 


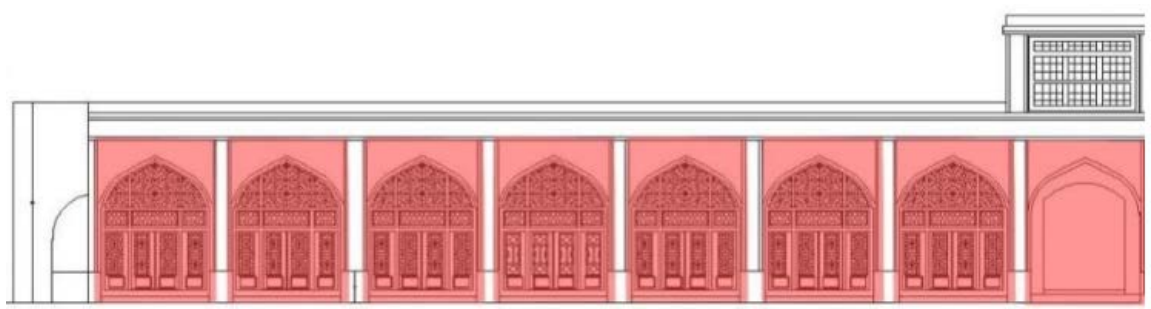

Figure 13. The courtyard western façade (main image source: Hajighasemi, 2003 [2]).

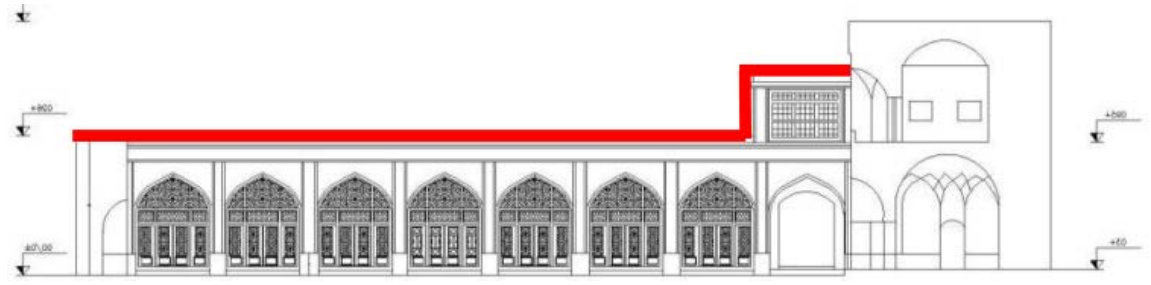

Figure 14. Proportions and combination of the courtyard western façade (Source of main image: Hajighasemi, 2003 [2]).

What intensifies the façade lateral rhythm is placement of an integrated inscription in its highest part, yet locating 8 twig arcs of openings and columns separating them which emphasizes on the vertical direction, has regulated the façade lateral state. Another sensible feature of this façade is using the repetition geometry in the openings, uniform and equal openings that are located beside each other without any priority. Except the mosque entrance opening (northern end opening), other openings have little through and are separated with tiled columns. What discriminates the entrance opening from other openings is not the shape and size but depth and brightness contrast which it has with other openings and so is completely identified. Except the entrance opening, other seven openings have been covered with wooden doors which are all opened to the mosque main harem (western harem). These doors are all equal (4 mates) and full of wooden Girih tiles with color glasses. In the glasses of these doors, 4 colors of blue, red, green and yellow have been purely used. The above part of the doors ornaments is all similar but the ornaments of the doors mates are different from each other. This similarity of doors that has generally intensified the similarity between the openings of this façade indicates a deliberation in this decision making. In fact, with this decision this façade (and of course the eastern façade) has turned to second rank facades in the courtyard and their repetitive but oriented rhythm unconsciously diverts the look towards the southern façade in the Kiblah direction.

The façade body from the bottom to the height of 1 meter has been covered with stone-cut plinth. This plinth has protected the building from serious damages and inevitable erosions. The façade level is completely covered with tile, except the openings through which has brick work. The edge of tiling ornaments have been separated here from each other with brick frames. Here, branch arcades are located among rectangular frames which have been dragged from the 
floor to beneath the façade upper inscription and has more emphasize on specific divisions and repetition element in the façade of this mosque. Except the different decorations of the middle opening door and tiling above the doors no distinction is observed in the size and shape of the façade openings shape. Whatever exists is repetition, to the extent that this similarity is also observed in the entrance opening which has the same width as other openings.

Above the entrance porch, there are chambers whose façade has a three-part division. Totally, ornaments of these windows seem simpler comparing the ornaments of the doors of the mosque western harem. In the left side margin (south) of this window, there is a tiled column which is accurately in the line with the lower column of the inscription and guides the eye from bottom-up and causes the chambers façade not to be visually independent and discontinuous from the mosque general façade (Figure 15 \& Figure 16). The rectangular dominant geometry on the chambers façade with finer divisions which are also rectangular, have an evident distinction with other twig arcs and divisions of the mosque façade, a distinction that even would sound more if the common tile work and color glasses didn't exist in it. This same distinction has made the chambers façade incongruous comparing the reset of façade.

The whole western façade has a recognizable edge in the bottom and top. The bottom edge is constituted of the single stair of the entrance to harem and the top edge of the row of brick on edge where the kennels are jutted of it. These two edges have an almost equal thickness and are the beginning and end of the facades two upper and lower end. Besides that, in designing and combining this façade, observation of some proportions may be observed as seen in Figure 17. Here, both entrance openings of the harem are located in a rectangular with proportions close to gold proportions and each one and a half opening is placed in one square. These proportions are also extendable to other openings of this façade.

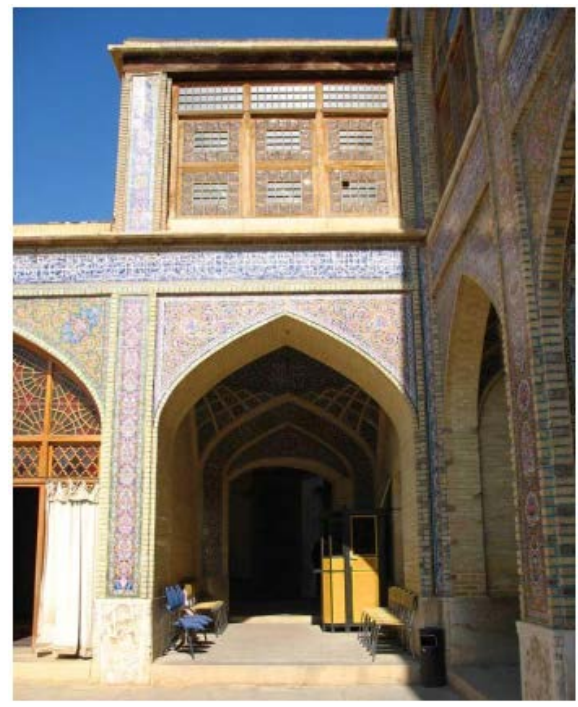

Figure 15. The mosque entrance from the courtyard interior. 


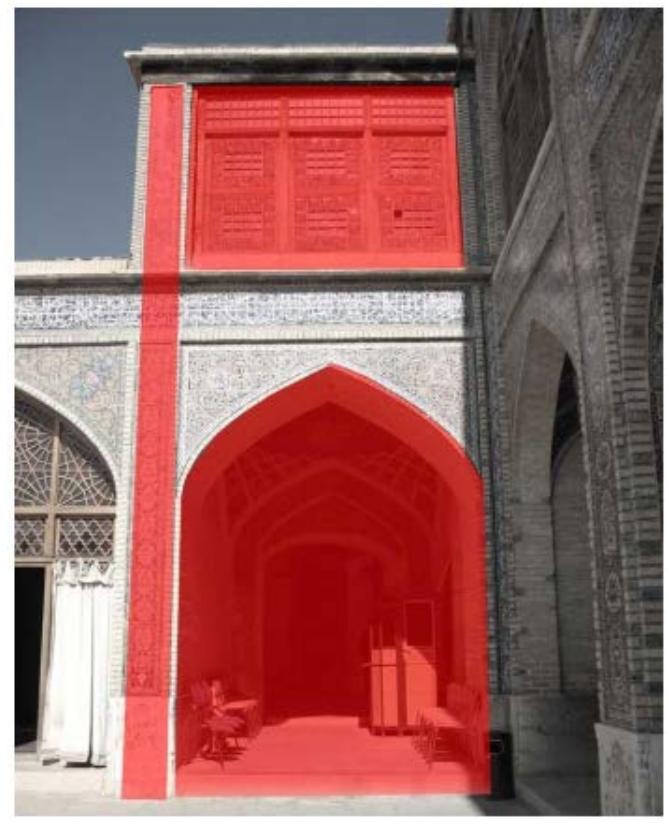

Figure 16. Proportions and entrance combination (Source: author).

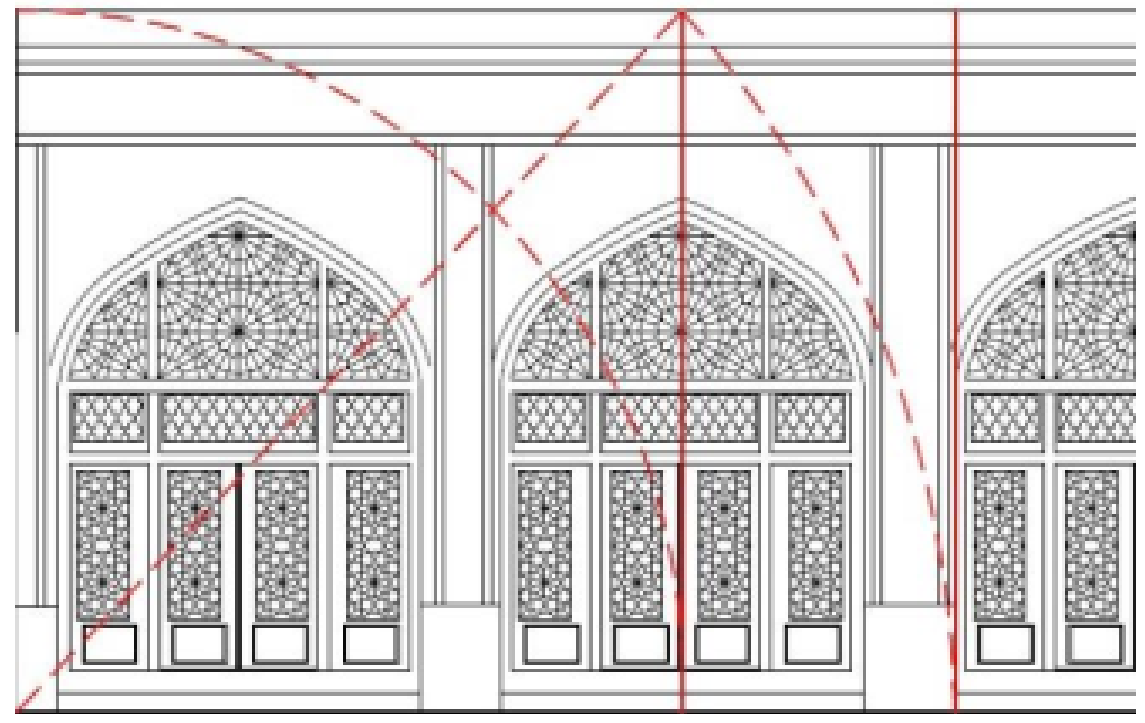

Figure 17. Proportions of the courtyard western façade openings (Source of façade figure: Hajighasemi, 2003 [2]).

With these descriptions, it seems that all these schemes have helped creation of a virtual depth in this façade. The flat façade with the ornamented body and different scales of ornaments where its details are perceived in various distances, have caused the façade to exit from the two-dimensional state and its depth and three-dimensional quality is increased.

But what is significant about this façade, totally and by mentioning these details, is using these features for emphasizing the Kiblah axis, a low-height and long façade whose length has been extended in the direction of Kiblah and for this reason, attracts the view to Kiblah more than attracting it to itself (of course 
this matter have been completed by the shape and situation of the mosque southern porch which will be pointed out in the following).

Moreover, the repetitive openings of this façade which don't have any height difference with each other and just in their ornaments a delicate variety is observed, have reinforced the rhythm of this orientation.

\subsubsection{Courtyard Eastern Façade (Façade of Eastern Porch and Harem)}

The courtyard eastern façade unlike its western façade is not flat. In fact, existence of a porch in this façade has created a depth. This façade is symmetrical with the western façade in its total plan, with this difference that these eight openings instead of being eight doors are twig arcs which form the porch in front of the eastern harem. Depth of this porch is located in contrast to the western façade where the doors are slightly sunken. This difference in depth has caused difference in light (Figure 18).

Doors of eastern harem are smaller and have fewer ornaments than western harem, wooden single mate doors which has mesh brick pores. These doors and pores have semi-circle arcs which are heterogeneous with the porch twig arc. Combination of columns which separates the twig arcs from each other are like the composition of the mosque western façade. In this façade, also the body towards the courtyard is covered of tile whose patterns are symmetrical with the patterns of mosque western façade. The roof face and plinths are similar to the opposite façade. Here, too, like the façade northern part, there are some chambers in the mosque upper level whose façade is completely similar to the opposite chambers. As we observe, sum of the features of this façade completely serve the orientation of the mosque internal space towards the Kiblah. A low-height, long and simple façade with repetitive openings and a rhythm similar to western façade leads the view towards Kiblah.

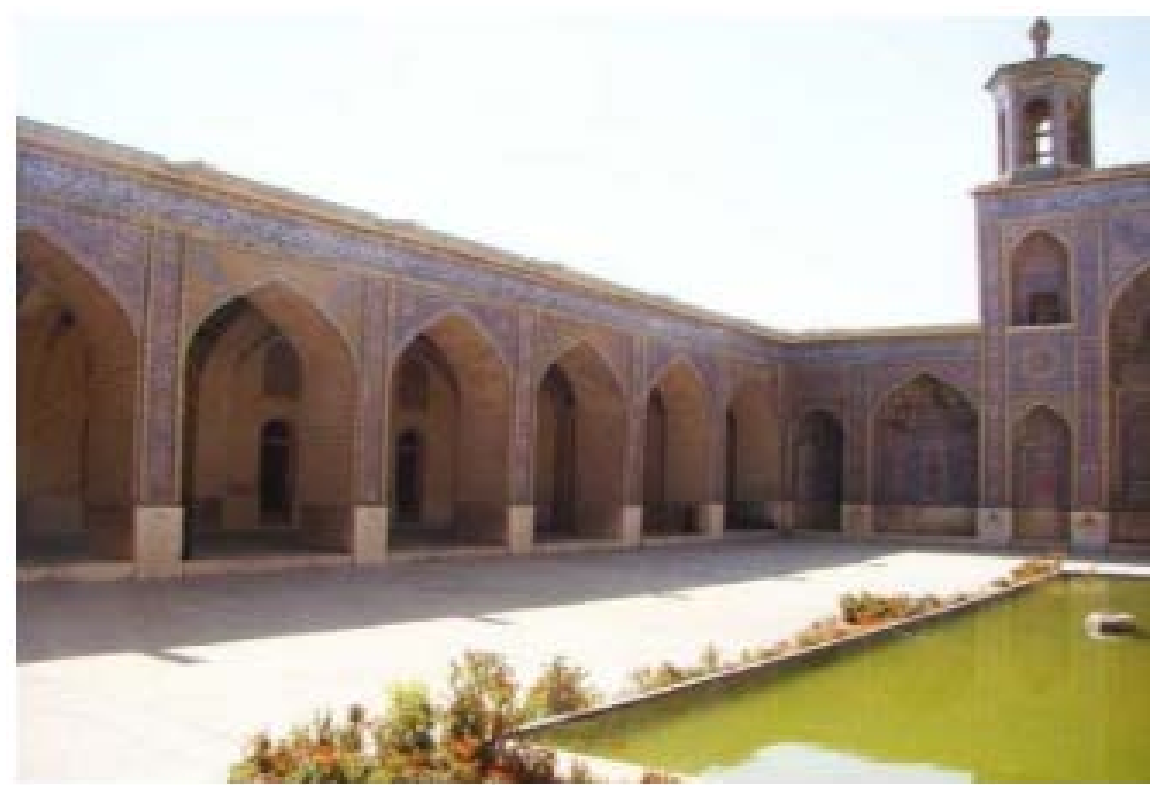

Figure 18. The courtyard eastern wall (Source: author). 


\subsubsection{In the Middle of the Courtyard}

With the aid of visual discontinuation between the mosque interior and outdoor, a different world is created in the courtyard. Since no higher building than the mosque exists in the surrounding, in the mosque there is just the mosque and the viewer and the sky (Figure 19 \& Figure 20). In fact, the viewer faces with three elements of surrounding bodies and sky and earth with a different quality in the courtyard, elements which are visually linked to each other. The image of blue sky has fallen on the earth (in the pool) and its blue color is seen on the body tiles. Besides that, this subject that how we see the courtyard sides from its middle has a great significant. Dimensions of the courtyard and its bodies and their proportions have created a hidden geometry which directly impacts the quality of viewing the monument sides. The mosque courtyard dimensions are 33 in 25 meters and its area is $825 \mathrm{~m}^{2}$. If we exactly stand in the middle of the courtyard northern side so that we rely on the wall behind us, the lot which is in our view field (according to human view angle which is 120 degrees) we can see Figure 21 \& Figure 22. We can experience the similar view angle by standing in the middle of southern side and glance at northern side. The width of the mosque courtyard is such that if this time we stand in the middle of one of eastern or western sides and look the opposite, we also see all the opposite side besides a small part of southern and northern sides (Figure 22). The interesting point here is that the extension of the supposed line which constitutes our view angle in this part is accurately coincident to the beginning of the mosque southern and northern porch and includes all the opposite side. Also, in both states, the pool in the middle of the courtyard is completely seen.

Placement of the pool in the porch middle indirectly adjust the view limit and the person who stands beside the pool is in the scope which is one of the most thoughtful points for viewing the courtyard sides. But the most important feature of the mosque courtyard space is its being oriented. This direction which specifically emphasizes the Kiblah has been created with the aid of organizing

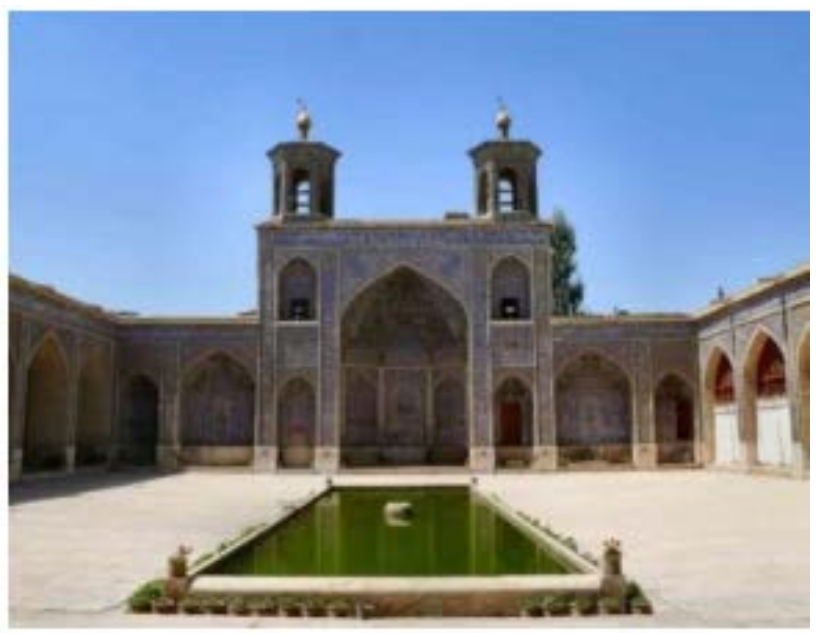

Figure 19. Northern porch (Source: author). 


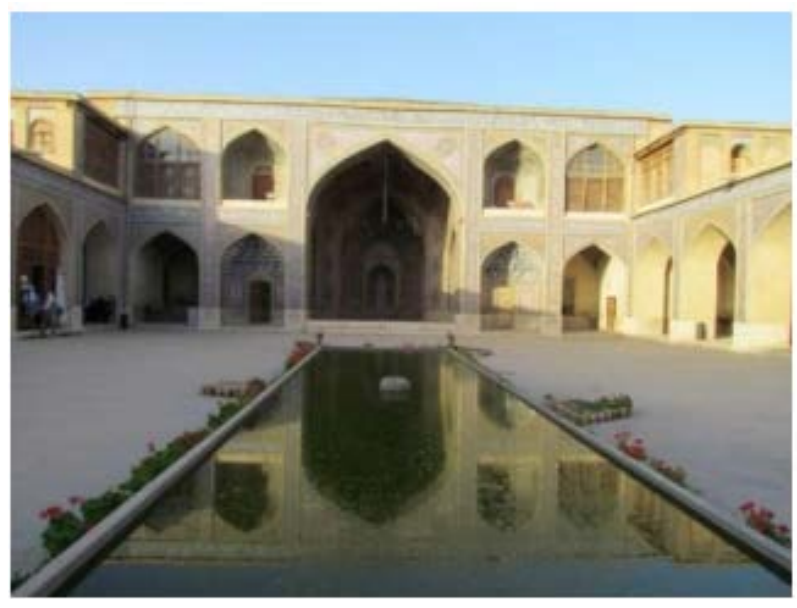

Figure 20. Southern porch and southern façade of the courtyard (Source: author).

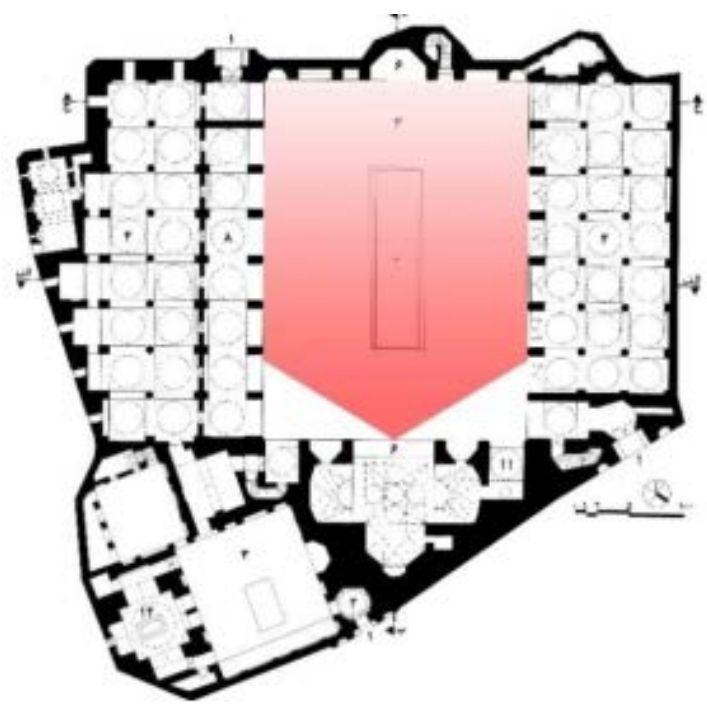

Figure 21. Source: Hajighasemi, 2003.

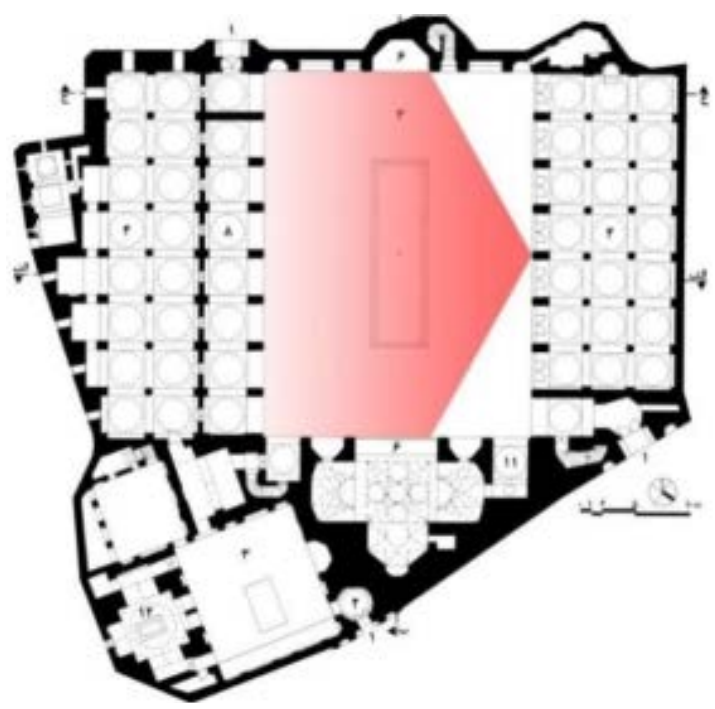

Figure 22. Source: Hajighasemi, 2003. 
the mosque main elements like harems and porches and their shape. Two porches in the surrounding and the courtyard in the middle that the direction of elongation of all of them is in the line of Kiblah, so both the shape of these spaces and organization of companions emphasize the Kiblah.

\subsection{Western Harem}

Western harem is the main harem of the mosque and its length is two times of its width (Almost 13 in $28.5 \mathrm{~m}$ ) and as we said its length is parallel to the Kiblah axis. The harem space has been divided in the width to three openings and in the length to seven openings that have totally created twenty-one parts of square shape (Figure 24). The mosque doesn't have vault house but each of these twenty-one parts has some ornaments in their ceiling which creates a though short image of the vault inside the harem

The harem eastern wall is in fact constituted of seven doors and columns between them, seven wooden doors ornamented with color glasses. With the aid of these same seven doors, western harem has found a close relation with the courtyard space. Among these seven openings, the middle opening either in respect of ornaments or the ceiling tiles is distinctive of others (Figure 23). The harem ceiling is based on 12 stone columns which have a complex stone cutting and one in between the direction of the spiral in their width is different. These columns have visually created three corridors which are located in the end of middle corridor of the altar and have clearly specified the Kiblah direction (Figure 24).

The northern and western walls of the harem have brick façade and there are some tiled frames in their middle. Few ornaments on the walls unconsciously draw the viewer attention to southern and eastern walls.

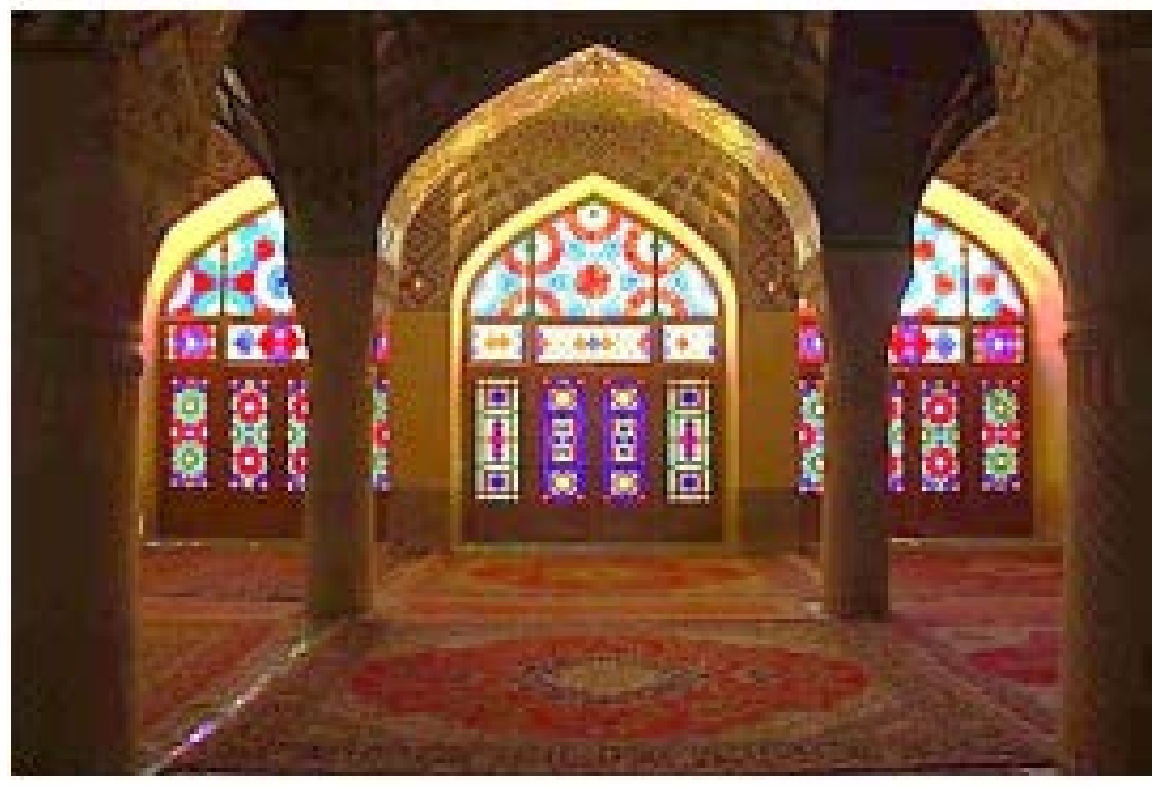

Figure 23. The middle opening of western harem (source: author). 


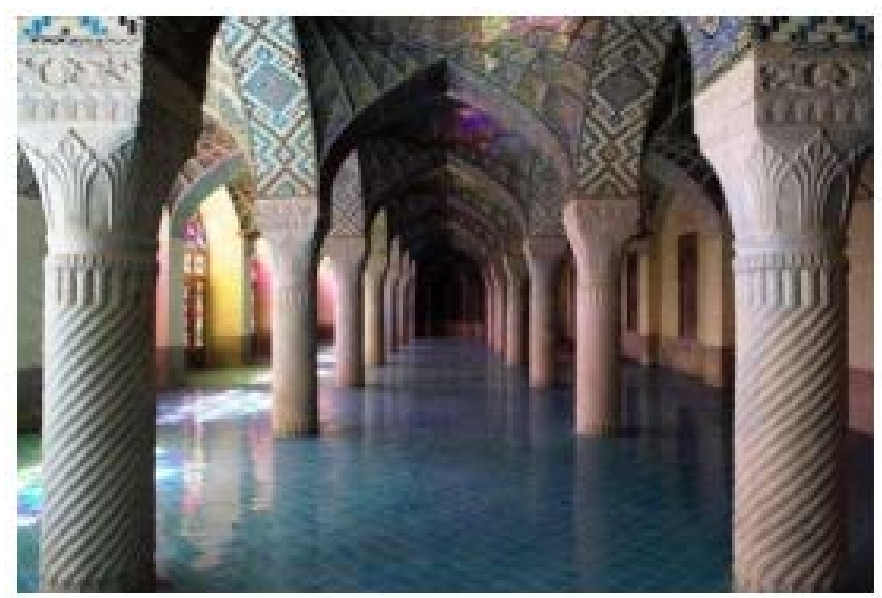

Figure 24. Source: author.

The southern wall is the Kiblah wall and is fully covered with tile and the eastern wall is the entrance way to the harem. When the viewer enters the harem through western wall doesn't see anything other than the wall itself. Here, relative simplicity of walls in front of the viewer (eastern wall) after entrance causes other walls to attract the attention of the viewer. At first in the left side the Kiblah wall is observed, then the light radiance from color glasses of the eastern wall attract the attention. From several hours before the sun rise till some hours before noon, the light passes color glasses and enters the harem. Daze due to this phenomenon prevents viewing outside. Unconsciously, in the mornings all attention is in interior but gradually by passing the noon this attention is reduced and looking outside gets easier.

\subsection{Eastern Harem}

Eastern harem is smaller and narrower than the western harem. The ratio of the length to width is 1 to 4 and seven columns stand in one row in its middle and keep the ceiling. The geometry of the space division here is similar to the western harem. Here we face 16 square-shaped parts with a structure similar to western harem. These square-shaped divisions have organized the adjacent harem similarly (Figure 25 \& Figure 26). The space light is supplied through relatively small doors which open to the courtyard and also through small windows locating in the southern and eastern sides.

Due to less significance of this harem to western harem, other lateral spaces have been placed in this façade. In the east of the harem, there is water supply chamber where a well is dogged. Since the water bucket had been pulled out from the well by cow it is called dungeon. From outside the mosque, a door is directly opened to the space where the well is located and a door from harem also opens to it. In front of the well and almost under the eastern harem, a relatively long corridor has been dogged which has been the path of the cow movement for pulling water from the well (notice the building plan in Figure 3). Besides that, the entrance path to Emamzadeh from the mosque interior has been 


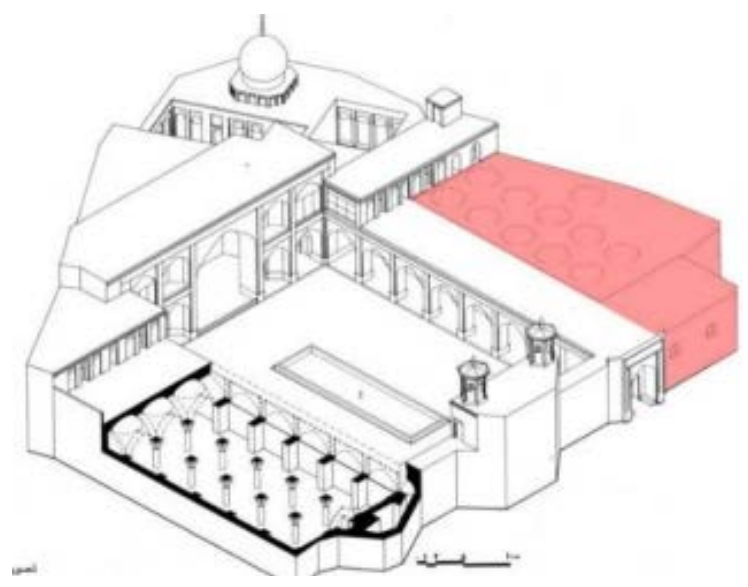

Figure 25. Eastern harem (Source of perspective image: Hajighasemi, 2003).

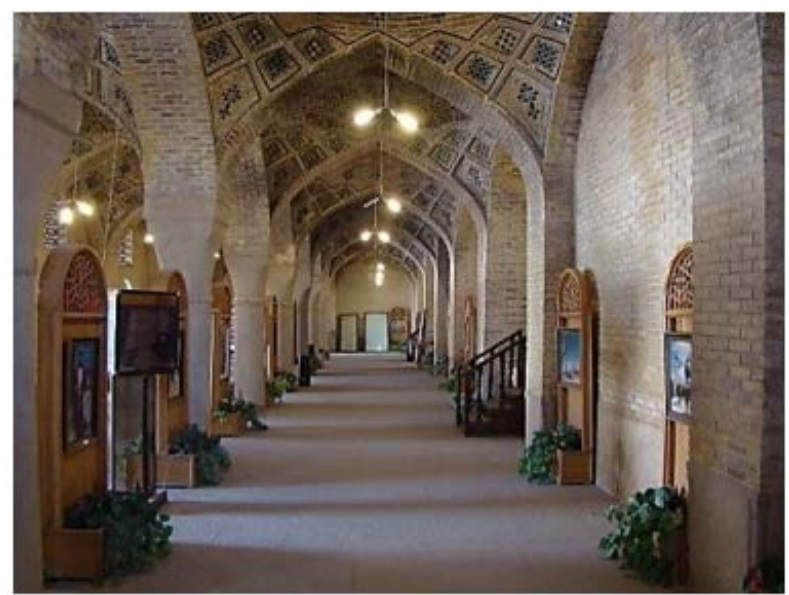

Figure 26. Eastern harem (Source: author).

devised here. This harem is much simpler and has les ornaments comparing the western harem. Its walls are covered with brick and just in its ceiling there is a combination of tiling and brick work (like what we see in the ceiling of the mosque entrance porch). Even the stone columns here are completely simple and without ornament and there is no sign of spiral stone cuttings like the stone cuttings of the western harem columns. As we see, the length of the eastern harem is equal to the courtyard length and all eight openings open from the courtyard to the harem. In the northern side of the harem there is a door which opens to Emamzadeh monument. Existence of these doors which open from the harem to various places and also other structural specifications like being simple and few ornaments have turned it to the mosque lateral harem. What is perceived from the features of this harem is a low-ornamented and second degree space that with the aid of low width and high length completely draws the attention towards Kiblah.

\section{Porches}

Porches are one of the most important space making elements of the mosque 
and they are the last elements we have addressed in this discussion. Nasirolmolk mosque is a two-porch mosque whose porches are located in the courtyard northern and southern sides. Having two porches has been an accurate and clever selection in its plan which has been selected relating to the shape and direction and place of standing the harems. Placement of two porches in the courtyard northern and southern sides has created a virtual and semi-tangible axis which is in the line with the harems lateral axis in two sides of the courtyard. This virtual axis has been reinforced in the middle of the courtyard due determining exact dimensions and the pool place, that is, in fact three parallel axels have been created inside the building that has given a certain direction to the mosque internal structure (Figure 3).

The northern porch is a big porch which has a considerable and distinct interior space (Figure 21) but on the contrary, the southern porch has been made with low depth to the extent that we can consider it a body making and not a complete porch (Figure 22). Some points are hidden in these differences, first that the southern porch (which is also the mosque Kiblah porch) though does not have a big space, but is the heights part of the building and is the most eminent part of the mosque in respect of façade. By entering the courtyard, this porch due to placement location and its distinct appearance is the first thing which attracts the attention. The northern porch which is an integrated coping though is more significant in respect of space making and area of interior space than the southern porch, but undoubtedly it is visually in the second rank of significant. In fact, the northern porch is a place for sitting and immediate relation with the courtyard space. This porch has a space where we can sit in front of the Kiblah and meditate while the landscape of southern porch and courtyard is in front of you. But the southern porch is not a place for sitting but it is an element for being seen and noticed and so instead of a big interior space has a distinct and high appearance. This distinct appearance with the aid of two minarets has been reinforced with the special shape on the top of the porch. These minarets are similar to bouquets and somehow lack of vault and bouquet in the mosque building has turned to a distinct and symbolic element in the Kiblah direction. Sum of features that we have mentioned in this discussion in the general plan and organizing the mosque space, from the shape and direction of the harems to features and proportions of the courtyard and form and location of porches has formed a space in this building which has two main features: introspection and orientation of the space. In fact, these two features are perceived together in the mosque space. The mosque form and arrangement of its elements completely emphasizes the Kiblah axis but this emphasis on the direction is only tangible in the mosque interior space and it is not perceived from outside (unlike the mosques which don't have vault and minarets).

\section{Summation and the Discussion Result}

- Mosque generally and Nasirolmolk mosque especially have many complexi- 
ties and delicate points. Dominance on these complexities and their perception requires more contemplation in the aspects of the building appearance. In this research, where its concentration is more on the monument architecture and its special organization, shortly the following results in response to the posed questions at the beginning of discussion were obtained:

- The whole building is in fact a collection of the mosque building and Emamzadeh monument which are located in close relation with each other and are interwoven, but this interrelation by no means reduces the mosque building independence. This union and linkage have been along with an accurate design and since the beginning has been noticed in the mosque construction.

- The mosque has an introverted structure that lack of vault and minaret in one hand, and low distance of the surrounding texture with its bodies have intensified it. Entrance in this between is just the building external presentation and representative of its most important sections.

- Emphasis on the Kiblah direction has been done with a special method in the architecture of this building. In harems organization in two sides of the courtyard in the direction of elongation and shape of the courtyard and harem, in determining the number of porches and their placement and finally in the shape and structure of two porches against each other, the Kiblah direction has been emphasized.

- Proportions in the building elements have been considered and in some places sizes have been used for emphasis on a special topic (for example, more height of the previous porch to other bodies in the courtyard).

- Detailed ornaments especially in the entrance portal and porches and western harem are noticeable and attract attention since the beginning of entering the spaces. Lateral spaces have apparently fewer ornaments and decorations everywhere in the building are not similar.

All designing schemes though various and numerous, they all have been used for uniting the general combination of the mosque architecture.

Surely, each of the discussed points in this article requires more description that each demands independent opportunity.

\section{Conflicts of Interest}

The authors declare no conflicts of interest regarding the publication of this paper.

\section{References}

[1] Molazadeh, K., et al. (2008) Encyclopedia of Iran Historical Buildings in Islamic Era, Mosques, Tehran, Islamic Art and Culture Research Institute.

[2] Hajighasemi, K. (2003) Ganjnameh, Culture Iran Islamic Architectural Monuments, Tehran, Rozaneh.

[3] Arnheim, R. (2009) Dynamics of Architectural Forms, Translated by Mehrdad Ghayomi Bidhendi, Tehran, Samt. 


\section{Postscript}

Arnheim [3] in the book of dynamics of architectural forms has addressed the imaginal subject that the mind makes by observing the objects from their totality and says the mind can combine an image of the building or sculpture objective three-dimensional shape from the landscapes multiplicity. This combination follows this fact that these various landscapes are not related, as if they are a series of pictures with which man tries to obtain an image of the building. Besides, as the viewer moves around the object, or the object stands in front of it, perceives a regular series of the pictures which gradually changes. Coherent of this series facilitates the identification of the object and all special landscapes refer to this same identification. For more study in this regard, refer to the book text. 